\title{
RUMAH ADAT LAKATUIL DI DESA BAMPALOLA, KECAMATAN ALOR BARAT LAUT, KABUPATEN ALOR NTT (KAJIAN HISTORIS, NILAI FILOSOFI, SERTA POTENSINYA SEBAGAI SUMBER BELAJAR SEJARAH)
}

\author{
*Amir Molbang \& Abraham Nurcahyo
}

\begin{abstract}
Abstrak
Penelitian ini bertujuan untuk mengetahui latar belakang sejarah Rumah Adat Lakatuil, nilaihistori, nilai filosofi, dan potensinya sebagai Sumber belajar sejarah. Lokasi penelitian ini berada di Desa Bampalola, Kecamatan Alor Barat Laut, Kabupaten Alor NTT. Dalam penelitian ini menggunakan pendekatan induktif dengan jenis penelitian deskriptif kualitatif. Sumber data yang digunakan dalam penelitian ini yaitu sumber data primer dan sumber data skunder. Teknik pengumpul data menggunakan teknik wawancara, observasi, dan dokumentasi. Validasi yang digunakan untuk menguji kebenaran dan keabsahan data menggunakan trianggulasi sumber. Sedangkan analisis data menggunakan analisis model interaktif H.B. Sutopo. Dari hasil penelitian diketahui bahwa Rumah Adat Lakatuil adalah rumah panggung berdinding bambu diatapi rumput ilalang berbentuk kerucut. Pada bagian puncak berukiran ular naga yang sedang membuka mulut menjurus kearah timur atau terbitnya matahari. Ciri khas yang lain adalah sebuah tangga yang menghubungkan tanah dan rumah panggung juga terdapat naga yang membuka mulut pada bagian kanan sedangkan bagian kiri terdapat sebuah rantai yang berfungsi sebagai pegangan pada tangan kiri. Dalam Rumah adat tersebut juga banyak peninggalanpeninggalan pusaka seperti Moko dan Gong. Bagi masyarakat Bampalola atau pengunjung yang hendak memasuki rumah adat harus menanggal kasut atau alas kaki karena tempat itu suci dan tidak boleh berbicara dengan kata-kata kotor. Setiap pengunjung yang hendak memasuki rumah adat tersebut harus mengawali langkahnya dengan kaki kanan dan tangan kanan dimasukkan kedalam mulut naga yang sedang terbuka sambil tangan kiri memegang rantai tali untuk berjalan menaiki tangga dan masuk kerumah adat. Keberadaan Rumah Adat Lakatuil mempunyai nilai-nilai histori dan filosofi dimana masyarakat Bampalola masih hidup dengan nilai-nilai adat serta menyatu dengan alam yang harmonis harus selalu diwariskan dan dilestarikan agar generasi yang akan datang tidak melupakan nilai-nilai sejarah yang ada. Nilai-nilai tersebuat dapat pula dijabarkan dalam pembelajaran IPS/Sejarah.
\end{abstract}

\section{Kata Kunci:Rumah Adat Lakatuil, Nilai Historis, Nilai Filosofi, Sumber Belajar Sejarah}

\section{Pendahuluan}

Bangsa Indonesia sejak dahulu kala sudah memiliki corak kebu-dayaan dan peradaban yang sangat tinggi. Berbagai bentuk tradisi dan peninggalan sejarah budaya nenek moyang berupa bangunanbangunan tua, candi-candi, rumah adat, benda-benda bersejarah, serta tata cara kebiasaan dan adat istiadat lainnya.
Semuanya masih dapat ditakjubi dan terus bercerita tentang masa lampau peradaban bangsa yang patut dibanggakan dan dilestarikan. Nusa Tenggara Timur adalah sebuah propinsi kepulauan yang terletak di wilayah Indonesia bagian timur yang memiliki banyak pulau. Namun dari jumlah tersebut hanya ada beberapa pulau yang dihuni oleh beraneka ragam suku bangsa

* Amir Molbang adalah Alumni Program Studi Pendidikan Sejarah IKIP PGRI MADIUN

* Abraham Nurcahyo adalah Dosen Program Studi Pendidikan Sejarah IKIP PGRI MADIUN 
dan kelompok etnis dengan latar bela-kang kebudayaan adat istiadat, kebiasaan, dan bahasa yang ber-variasi. Keanekaragaman ini merupakan kekayaan yang tetap dan terus dilestarikan demi menjunjung tinggi nilai-nilai kebudayaan yang ada di Nusa Tenggara Timur pada khususnya dan di Indonesia pada umumnya. Kabupaten Alor sebagai salah satu dari 21 Kabupaten/Kota di Provinsi Nusa Tenggara Timur adalah wilayah kepulauan dengan 15 pulau yaitu 9 pulau yang telah dihuni dan 6 pulau lainnya belum atau tidak berpenghuni.

Kabupaten Alor mempunyai karakteristik yang unik dengan kekayaan budaya yang bernilai tinggi dan masih hidup di masyarakat diantaranya bahasa daerah sebanyak 17 dengan 52 dialek, terdapat 4 etnis, 15 perkampungan tradisional dan sejumlah upacara adat, alat musik, tarian dan nyanyian rakyat serta berbagai motif tenun ikat yang unik dan mempunyai daya tarik bagi wisatawan baik wisatawan domestik maupun mancanegara (Dinas Kebudayaan dan Pariwisata Kabupaten Alor, 2013: 01).

Kabupaten Alor terdiri dari berbagai suku, bahasa, dan agama yang berbedabeda. Begitu juga dengan kebudayaan yang dihasilkan antara desa yang satu dengan yang lain berbeda, seperti salah satu desa bernama Desa Bampalola adalah salah satu dari sekian banyak desa di Kabupaten Alor yang terletak di Kecamatan Alor Barat Laut.
Bangunan rumah adat Lakatuil ini berupa rumah panggung berdinding bambu, dan diatapi dengan rumput ilalang yang berbentuk kerucut. Pada bagian atasnya berukiran naga yang sedang membuka mulut menjurus ke arah Timur yang merupakan arah terbitnya matahari. Ciri khas dari rumah adat Lakatuil adalah tangga yang menghubungkan tanah dengan rumah panggung juga berukiran naga.

Pembangunan Rumah Adat Lakatuil ini dikerjakannya masyarakat secara gotong royong dengan dikepalai oleh seorang arsitek atau kepala tukang. Setelah rumah adat selesai dibuat maka musim kelaparan yang melanda desa Bampalola juga hilang, tanaman dan hasil hutan masyarakat kembali subur dan dapat diolah menjadi makanan. Kehidupan masyarakat mulai membaik. Setelah kejadian tersebut maka rumah Lakatuil di jadikan rumah adat di desa Bampalola. Selain itu rumah adat Lakatuil ini juga mempunyai sejarah dimana masyarakat meyakini bahwa apa yang dilakukan dirumah adat ini bisa mendatangkan kesejahteraan bagi masyarakat desa karena mereka percaya nenek moyang mereka berasal dari tanah atau timbul secara ghaib dari dalam tanah.

Melalui pembangunan rumah adat Lakatuil tersebut diatas bisa dijadikan sebagai sumber belajar yaitu pembelajaran IPS sebab banyak terdapat nilai-nilai filosofi sejarah, kebudayaan yang dapat kita pelajari. Berdasarkan latar belakang di atas, 
maka mendorong penulis untuk menelusuri, meneliti, dan mengkaji dengan judul penelitian Rumah Adat Lakatuil di Desa Bampalola, Keca-matan Alor Barat Laut, Kabupaten Alor NTT (Kajian Historis, Nilai Filosofi Serta Potensinya Sebagai Sumber Belajar Sejarah).

Berdasarkan Rumusan masalah diatas maka tujuan peneltian ini adalah untuk mendeskripsikan:

1. Sejarah Rumah Adat Lakatuil di Desa Bampalola Kecamatan Alor Barat Laut Kabupaten Alor NTT.

2. Fungsi dari rumah adat Lakatuil bagi kehidupan masyarakat di Desa Bampalola Kecamatan Alor Barat Laut Kabupaten Alor NTT.

3. Makna dari ukiran yang terdapat pada rumah adat Lakatuil di Desa Bampalola, Kecamatan Alor Barat Laut Kabupaten Alor NTT.

4. Nilai-nilai serta potensi dari Rumah Adat Lakatuil di Desa Bampalola Kecamatan Alor Barat Laut Kabupaten Alor NTT

\section{Kajian Pustaka}

A. Rumah Adat

\section{Pengertian Rumah Adat}

Rumah-rumah adat di indonesia memiliki bentuk dan arsitektur masingmasing daerah sesuai dengan budaya adat lokal. Pada umumnya dihiasi ukiran-ukiran indah, pada jaman dulu, rumah adat yang tampak paling indah biasa dimiliki para keluarga kerajaan atau ketua adat setempat menggunakan kayu-kayu pilihan dan pengerjaannya dilakukan secara tradisional melibatkan tenaga ahli dibidangnya, Banyak rumah-rumah adat yang saat ini masih berdiri kokoh dan sengaja dipertahankan dan dilestarikan sebagai simbol budaya Indonesia.

Rumah adat merupakan bangunan rumah yang mencirikan kekhasan bangunan suatu daerah di Indonesia yang melambangkan kebudayaan dan ciri khas masyarakat setempat menyangkut dengan kepribadian masyarakat daerah tersebut. Rumah Adat adalah merupakan bangunan rumah yang mencirikan atau khas bangunan suatu daerah di Indonesia yang melambangkan kebudayaan dan ciri khas masyarakat setempat. Indonesia dikenal seagai negara yang memiliki keragaman dan kekayaan budaya, beraneraka ragam bahasa dan suku dari sabang ampai merauke sehingga Indonesia memiliki banyak koleksi rumah-rumah adat.

Dengan demikian pengertian dari Rumah adat tersebut adalah suatu bangunan yang bentuk struktur, fungsi, makna, ragam hiasan cara pembuatannya diwariskan secara turun-temurun dan dapat dipakai untuk melakukan aktivitas kehidupan dengan sebaik-baiknya.

\section{Sejarah Rumah Adat Lakatuil}

Sejarah singkat rumah adat Lakatuil di desa Bampalola. Masyarakat Bampalola percaya nenek moyang mereka berasal dari 
tanah atau timbul secara ghaib dari dalam tanah. Ia disebut dengan nama Raja Tanah (foaifen). Raja Tanah sendiri hidup sekitar pada abad ke-13 dan tidak ada satu orangpun yang tau dari mana Raja Tanah itu berasal. Gua tempat munculnya raja tanah di debut dengan nama tula gadong yang artinya rumah Tuhan. Raja Tanah kemudian menikah dengan Buifedi. Mereka kemudian tinggal di kampung lama di bawa kaki gunung Raja. Untuk memenuhi kebutuhan hidup dan melindungi diri dari hewan buas, maka Raja Tanah dan istrinya membangun sebuah rumah yang diberi nama Laktuil yang artinya merah dan tinggi.

Merah menandakan keberanian dan keperkasaan dari rumah adat lakatuil, sedangkan tinggi karena rumah adat dibuat seperti rumah panggung dan memiliki atap berbentuk limas yang tinggi. Muhamad Asri (56: 2014) Juru bicara adat Desa Bampalola menceritakan bahwa Kampung Lama menjadi salah satu kerajaan besar di pulau alor yakni kerajaan Lakatuil.

Kerajaan Laktuil mencapai puncak kejayaannya pada masa pemerintahan Raja Baololong, dan memiliki wilayah yang luas dihampir sebagian Pulau Alor. Sehingga sampai sekarang banyak turunan dari Bampalola yang ada di sebagian pulau alor. Pada akhir abad ke-14 raja Baololong meninggal dunia dan akhirnya kerajaan Lakatuil mengalami kemerosotan dan punah. Setelah agama Islam masuk masyarakat mulai melupakan kebiasaanya yang menyembah pohon dan batu-batu besar. Pada awal abad 20 sebelum Indonesia merdeka desa Bampalola berada di bawah kepemimpinan Desa Dulolong dan dikuasai bangsa Barat. Setelah Indonesia merdeka dan pada tahun 1965, masyarakat bampalola hidup seperti masyarakat biasa pada umunya yaitu bertani, berkebun dan mengelola hasil hutan.

Seluruh masyarakat Bampalola mengerjakannya secara gotong royong. Setelah rumah adat selesai dibuat maka musim kelaparan yang melenda desa Bampalola juga hilang, tanaman dan hasil hutan masyarakat kembali subur dan dapat diolah menjadi makanan. Kehidupan masyarakat mulai membaik. Setelah kejadian tersebut maka rumah Lakatuil di jadikan rumah adat di desa Bampalola. Setelah rumah adat lakatuil dibangun maka suku-suku yang lain mulai membangun rumah adat yang lain. Dan kampung lama (doita) tempat berdirinya rumah adat Lakatuil di jadikan kampung Adat.

\section{Fungsi Rumah Adat Lakatuil}

Rumah adat Lakatuil memiliki berbagai fungsi dalam kehidupan masyarakat Bampalola. Fungsi tersebut antara lain:

a. Rumah adat Lakatuil berfungsi sebagai tempat tersimpannya benda-benda purbakala atau cagar budaya seperti moko dan gong.

b. Rumah adat Lakatuil berfungsi sebagai tempat berkumpulnya masyarakat 
Bamapalola untuk musyawarah mufakat dalam berbagai hal.

c. Rumah adat Lakatuil berfungsi sebagai tempat pelaksanaan berbagai upacara adat seperti upacara makan padi baru dan makan jagung baru (bate baloe).

d. Rumah adat Lakatuil berfungsi sebagai tempat untuk menyelesaikan berbagai masalah adat dalam masyarakat Bampalola.

e. Rumah adat Lakatuil berfungsi sebagai tempat berkumpulnya para tokoh-tokoh adat dari 10 kampung Adang

f. Rumah adat Lakatuil juga berfungsi sebagai obyek wisata bagi wisatawan baik wisatawan domestik maupun mancanegara, Ina Holo ( 64 : 2014).

\section{B. Nilai Historis}

Sering orang khilaf bahwa sejarah itu tidak mempunyai nilai. Nilai sejarah (the value of history), sebagaimana yang bisa disebutkan dalam salah satu definisi sejarah, bahwa sejarah adalah studi tentang kehidupan manusia di dunia yang berhubungan dengan kamajuan, lembaga, budaya dan peradaban dan yang sangat penting adalah orang harus tau apa yang dikerjakan orang lain.

Memang tidak salah bahwa sejarah adalah induk kebenaran, saksi kelampauan, dan mengiklankan sesuatu yang akan datang. Ditambahkan bahwa sejarawan seharusnya bertindak tepat, benar, dan tidak bernafsu, juga baik untung maupun takut, dendam, dan sayang, membuat mereka terisolasi dari kebenaran Robin Winks (dalam Pranoto, 2010: 06).

Historis atau sejarah dapat diartikan sebagai peristiwa atau kejadian yang benar-benar terjadi pada masa lampau yang mempunyai pengaruh cukup besar sehingga peristiwa tersebut mendapat andil dalam peradaban kehidupan manusia dalam suatu ruang lingkup tertentu (A. Marwick, 1971: 97-129). Sejarah atau History adalah sebagai bahan kajian dalam hal mempelajari dan juga menerjemahkan dari berbagai informasi, berdasarkan catatan yang sudah dibuat oleh banyak orang atau dari keluarga, komunitas dan lain sebagainya.

Pengertian sejarah meliputi akan dua hal. Pertama, pengetahuan yang membahas mengenai kejadian yang sudah terjadi di masa lampau dan kedua adalah dengan melihat dari pengetahuan pada rangka cara berpikir secara historis. Sementara sejarawan adalah sebutan bagi orang yang mempelajari tentang sejarah itu sendiri. Dengan demikian nilai dan historis di atas dapat disimpulkan bahwa suatu kejadian atau peristiwa masa lampau mempunyai nilai-nilai historis yang sangat tinggi dan tidak akan terlupakan. 


\section{Nilai Filosofis}

Nilai adalah sesuatu yang baik selalu diinginkan, dicita-citakan dan dianggap penting oleh seluruh manusia sebagai anggota masayarakat. Karena itu, sesuatu dikatakan memiliki nilai apabila berguna dan berharga (nilai kebenaran), indah (nilai estetika), baik (nilai-moral atau etis) dan religious (nilai agama). (Elly M Setiadi, 2006: 31). Nilai (Value) merupakan inti dari sistem kebudayaan. (Rusli, 2001: 65).

Kata "filsafat" berasal dari bahasa Yunani kuno, yaitu dari kata "philos" dan "Shopia". Philos artinya cinta yang sangat mendalan, dan sophia artinya kearifan atau kebijakan. Jadi arti filsafat secara hrfiah adalah cinta yang sangat mendalam terhadapat kearifan atau kebijakan. Filsafat dapat diartikan sebagai suatu pendirian hidup (individu) dan dapat juga disebut pandangan hidup (masyarakat).

Berfilsafat merupakan salah satu kegiatan/ pemikiran manusia memiliki peran yang penting dalam menentukan dan menemukan eksistensinya. Berfilsafat berarti berpikir, tetapi tidak semua berpikir dapat dikategorikan berfilsafat. Berpikir yang dikategorikan berfilsafat adalah apabila berpikir tersebut mengandung tiga ciri yaitu radikan, sistematis dan universal. Dengan demikian nilai filosofi di atas dapat disimpulkan bahwa nilai memiliki kecenderungan untuk menetap walaupun masih berubah.

\section{Sumber Belajar}

\section{Pengertian Sumber Belajar}

Sumber belajar adalah segala sesuatu yang dapat dimanfaatkan oleh siswa untuk mempelajari bahan dan pengalaman belajar sesuai dengan tujuan yang hendak dicapai. Menurut Wina Sanjaya (2009: 174) bahwa Sumber belajar merupakan salah satu komponen dalam kegiatan belajar yang memungkinkan individu yang memperoleh pengetahuan, kemampuan, sikap, keyakinan, emosi, dan perasaan. Sumber belajar memberikan pengalaman belajar dan tanpa sumber belajar maka tidak mungkin terlaksana proses belajar mengajar dengan baik.

Crow and Crow (1958) dalam Suyono (2011: 12), belajar merupakan diperolehnya kebiasaan-kebiasaan, pengetahuan dan sikap baru. Hilgard bahwa belajar adalah suatu proses dimana suatu perilaku muncul atau berubah karena adanya respon terhadap suatu situas. Belajar merupakan suatu aktivitas atau suatu proses yang memperolehpengetahuan, meningkatkan keterampilan, memperbaiki perilaku, sikap, dan mengokohkan kepribadian (dalam Suyono, 2012 :12).

\section{Sumber Belajar Sejarah}

Sejarah sebagai peristiwa yang terjadi pada masa lampau, dapat 
diungkap kembali oleh para ahli sejarah berdasarkan sumber-sumber sejarah yang dapat ditemukan. Meskipun demikian, tidak semua peristiwa masa lampau dapat diungkap secara lengkap karena terbatasnya sumber sejarah. Dalam penulisan sejarah, peran atau keberadaan sumber sejarah menjadi sesuatu yang tidak bisa diabaikan. Sumber sejarah merupakan bahan utama yang dipakai untuk mengumpulkan informasi yang berkaitan dengan subjek sejarah.

Untuk memperolehnya seseorang dapat memanfaatkan museum, perpustakaan, arsip nasional, arsip daerah sebagai tempat untuk mendapatkan informasi yang terkait dengan subjek sejarah yang akan ditulis. Ditinjau dari wujudnya, secara umum sumber sejarah dibedakan menjadi dua, yaitu: sumber primer dan sumber sekunder.

Sumber Primer berkaitan langsung dengan peristiwa yang akan diceritakan. Sumber primer ini dapat berupa kesaksian langsung dari pelaku sejarah (sumber lisan), dokumendokumen, naskah perjanjian, arsip (sumber tertulis), dan benda atau bangunan sejarah atau benda-benda arkeologi (sumber benda). Sumber benda adalah keterangan tentang peristiwa pada masa lampau yang diperoleh melalui benda peninggalan.
Fosil, alat-alat atau benda-benda budaya (kapak, tombak, gerabah, perhiasan, manik-manik, dan sebagainya), tugu peringatan, bangunan, dan sebagainya merupakan peninggalan sejarah yang sangat penting, terutama bagi masyarakat pra-aksara. Sumber sekunder adalah Kesaksian dari siapa pun yang bukan merupakan saksi pandangan mata, yakni orang yang tidak hadir pada peristiwa yang dikisahkan.

\section{Potensi Rumah Adat Lakatuil} sebagai Sumber Belajar Sejarah

Bangunan rumah adat Lakatuil ini berupa rumah panggung berdinding bambu, dan diatapi dengan rumput ilalang yang berbentuk kerucut. Pada bagian atasnya berukiran naga yang sedang membuka mulut menjurus ke arah Timur yang merupakan arah terbitnya matahari. Ciri khas dari rumah adat Lakatuil adalah sebuah tangga yang menghubungkan tanah dengan rumah panggung juga berukiran naga.

Masyarakat Bampalola adalah masyarakat yang masih hidup dengan nilai-nilai adat serta menyatu dengan kehidupan alam yang harmonis. Lewat simbol rumah adat dan aneka bendabenda purbakala serta berbagai jenis alat musik menambah daya mistis dan misteri yang belum tersingkat hingga kini. Namun, yang pasti hidup di sebuah bukit yang tidak ada sumber air itu mereka hidup dengan damai dan 
tenteram serta alam yang memberikan kemakmuran bagi anak cucu hingga kini. Rumah Adat Lakatuil sebagai sumber belajar sejarah ini dapat direlevansikan disekolah tingkat SMA kelas XI.

\section{Metode Penelitian}

\section{A. Lokasi dan Waktu Penelitian}

Penelitian ini berlokasi di Desa Bampalola Kecamatan Alor Barat Laut Kabupaten Alor. Penentuan lokasi ini didasarkan atas dasar pertimbangan bahwa peneliti dapat mengumpulkan informasi dengan mudah atau memudahkan peneliti dalam mengumpulkan data karena ada objek yang diteliti yaitu Rumah Adat Lakatuil di Desa Bampalola Kecamatan Alor Barat Laut Kabupaten Alor NTT (Kajian Historis, Nilai Filosofi Serta Potensinya Sebagai Sumber Belajar Sejarah) terdapat informan yang dapat memberikan data yang dibutuhkan

\section{B. Pendekatan dan Jenis Penelitian}

Berdasarkan tema yang di ambil penulis tentang Rumah Adat Lakatuil di Desa Bampalola Kecamatan Alor Barat Laut Kabupaten Alor NTT (Kajian Historis, Nilai Filosofi Serta Potensinya Sebagai Sumber Belajar Sejarah) ini menggunakan Pendekatan Kualitatif. Metode Kualitatif ini dipilih berdasarkan pertimbangan bahwa data yang diperoleh adalah informasi dan dokumen mengenai Rumah Adat Lakatuil di Desa
Bampalola Kecamatan Alor Barat Laut Kabupaten Alor NTT dari dahulu hingga saat ini.

Denzin dan Lincoln (dalam Moleong, 2011: 05) mengatakan bahwa Penelitian kualitatif adalah penelitian yang menggunkan latar alamiah, dengan maksud menafsirkan fenomena yang terjadi dan dilakukan dengan jalan melibatkan berbagai metode yang ada. Jenis penelitian yang dilakukan yaitu jenis penelitian deskriptif.

Bagian deskriptif dalam catatan data ini meliputi potret subjek, rekonstruksi dialog, deskripsi keadaan fisik, struktur tentang tempat, dan barang-barang lain yang ada di sekitarnya. Demikian juga, catatan tentang berbagai peristiwa khusus (termasuk siapa yang terlibat dengan cara bagaimana, gerak-geriknya, dan juga tingkah laku atau sikap penelitiannya (Sutopo, 2002: 74).

\section{Sumber Data}

\section{Sumber Data Primer}

Sulistyo Basuki (dalam Andi Praswoto, 2014: 112), menyatakan bahwa sumber primer adalah sumber yang merupakan bagian dari atau langsung berhubungan dengan peristiwa sejarah. Jika pristiwa yang dikaji masih berada dalam ingatan orang yang masih hidup, sumber primer meliputi kesaksian orang-orang 
yang dapat dikelompokkan pada saksi yang dapat dipercayai.

Nazir (dalam Andi Praswoto, 2014: 113) menyatakan sumbersumber dasar yang merupakan bukti atau saksi utama dari kajian yang lalu adalah yang disebut data primer. Menurut (Iqbal, 2004: 19) Sumber data primer merupakan sumber data yang diperoleh atau dikumpulkan dilapangan oleh orang yang melakukan penelitian atau yang bersangkutan yang memerlukannya.

\section{Sumber Data Sekunder}

Menurut Surakhmad (dalam Andi Praswoto, 2014: 113) menyatakan bahwa Sumber data sekunder adalah catatan tentang adanya suatu peristiwa ataupun catatan-catatan yang jaraknya telah jauh dari seumber asli.

Sumber yang mengutip dari sumber lain dan atau sebagai hasil penggunaan sumber-sumber lain, tidak langsung merupakan dokumen historis yang murni, ditinjau dari kebutuhan dari penyelidik.. Sumber data sekunder menurut Iqbal (2004: 19) adalah data yang diperoleh atau dikumpilkan oleh seseorang yang melakukan penelitian dari sumber-sumber yang telah ada

\section{Teknik Pengumpulan Data}

Menurut Sugiyono (2008: 224) teknik pengumpulan data merupakan langkah yang paling strategis dalam penelitian, karena tujuan utama dari penelitian adalah mendapatkan data. Tanpa mengetahui teknik pengumpulan data, maka peneliti tidak akan mendapatkan data yang memenuhi standar data yang ditetapkan. Pengumpulan data dalam penelitian ini dilakukan dengan wawancara, observasi, dan dokumentasi tertulis/arsip.

\section{E. Prosedur Penelitian}

Penelitian ini tentang Rumah adat lakatuil di desa bampalola, kecamatan alor barat laut, kabupaten alor ntt (kajian historis, nilai filosofi, serta potensinya sebagai sumber belajar sejarah) yang bisa diwariskan kepada masyarakat sebagai sumber belajar sejarah dilakukan selama 6 bulan. Penelitian dilaksanakan mulai dari bulan Februari sampai dengan bulan Juli tahun 2015. Tahapan dalam penelitian ini tersusun sebagai berikut:

1. Tahap Persiapan

Pada tahap persiapan ini menyangkut penentuan tema dan pengajuan judul, pengamatan atau melakukan observasi awal. Kegiatan tersebut dilakukan pada bulan Februari. Setelah mendapatkan persetujuan dari dosen pembimbing, maka kegiatan selanjutnya adalah mengadakan observasi awal terhadap objek penelitian agar memperoleh suatu gambaran tentang lokasi dan narasumber yang akan digunakan sebagai pendukung dalam pelaksanaan penelitian. 
2. Tahap Penelitian

$$
\text { Pada tahapan ini dilakukan }
$$
pengumpulan data, pengolahan data, dan analisis data. Dalam tahapan pengumpulan data peneliti mendapatkan data dari berbagai sumber. Sumber yang didapat merupakan hasil dari wawancara, sumber dokumen, dan pengamatan atau observasi secara lansung.

3. Tahap Laporan

Pada tahap akhir merupakan tahap penyelesaian laporan atau penyajian data. Penyusunan laporan didasarkan pada hasil analisis data yang sudah didapatkan pada tahap sebelumnya. Laporan atau sajian dilakukan secara benar dan tersusun sistematis. Selain itu data yang disajikan merupakan data yang sesuai dengan fakta dan dapat dipertanggung jawabkan kebenarannya.

\section{F. Teknik Keabsahan Data}

Untuk mendapatkan data yang valid dalam penelitian ini, peneliti menggunakan teknik validitas data sebagai berikut, Triangulasi metode adalah pengumpulan data yang sama dengan menggunakan metode pengumpulan data yang berbeda, serta diusahakan mengarah pada sumber data yang sama untuk menguji kemantapan informasi. Penggunaan metode pengumpulan data yang berbeda, dan bahkan lebih jelas untuk diusahakan mengarah pada sumber data yang sama untuk menguji ke-mantapan informasinya. Misalnya, untuk memantapkan validitas data mengenai suatu keterampilan seseorang dalam bidang tertentu.

Peneliti menggunakan metode pengumpulan data yang berupa kuesioner. Kemudian dilakukan wawancara mendalam pada informan yang sama dan hasilnya diuji dengam pengumpulan data sejenis dengan menggunakan teknik observasi pada saat orang tersebut melakukan kegiatannya atau perilakunya (Sutopo, 2002: 80).

Triangulasi sumber data adalah mengumpulkan data dari berbagai sumber data digunakan untuk menguji kebenaran tentang pelaksanaan pembelajaran sejarah. Cara ini mengarahkan peneliti agar di dalam mengumpulkan data, wajib menggunakan beragam sumber data yang tersedia. Artinya, data yang sama atau sejenis, akan lebih mantap kebenarannya bila digali dari beberapa sumber data yang berbeda. Triangulasi sumber data yang memanfaatkan jenis sumber data yang berbeda-beda untuk menggali data yang sejenis (Sutopo, 2002: 79).

Review informan merupakan usaha pengembangan validitas penelitian. Digunakan untuk mereview informan, apakah data hasil wawancara 
sudah valid dan sesuai dengan kesepakatan atau belum. Pada waktu peneliti sudah mendapatkan data yang cukup lengkap dan belum utuh dan menyeluruh, maka unit-unit laporan yang telah disusunnya perlu dikomunikasikan dengan informannya, khususnya yang dipandang sebagai informan utama (Sutopo, 2002: 83).

Adapun teknik trianggulasi sumber dapat dilihat dari bagan ini:

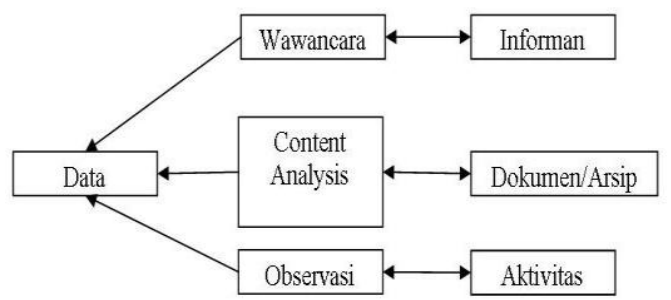

Bagan 3. 1. Trianggulasi Sumber (Sutopo, 2002: 80)

\section{G. Teknik Analisis Data}

Analisis data merupakan bagian yang penting dalam metode ilmiah, karena data tersebut dapat diberi arti dan makna yang berguna dalam memecahkan masalah penelitian. Data mentah yang telah dikumpulkan perlu dipecahkan dalam kelompok-kelompok, diadakan kategorisasi, dilakukan manipulasi, serta diperas sedemikian rupa. Sehingga data tersebut mempunyai makna untuk menjawab masalah dan bermanfaat untuk menguji hipotesis (Nazir, 2009: 346).

Sedangkan Miles dan Huberman (dalam Sugiyono, 2008: 246-253) mengemukakan bahwa dalam analisis data kualitatif dilakukan secara interaktif dan berlangsung secara terus menerus melalui reduksi data (data reduction), penyajian data (data display) dan penarikan kesimpulan (conclusion drawing atau verification).

1. Tahap Reduksi data

Dalam tahap reduksi data, peneliti melakukan proses seleksi, pemfokusan, penyederhanaan dan abstraksi data dari sumber penelitian. Reduksi data merupakan bagian dari proses analisis yang mempertegas, memperpendek, membuat fokus, membuang hal-hal yang tidak penting dan mengatur data sedemikian rupa sehingga simpulan penelitian dapat dilakukan. Peneliti melakukan tahap reduksi data dengan membaca secara cermat objek penelitian dan kemudian dibagi ke dalam kategori sesuai kajian yang peneliti amati.

2. Tahap Penyajian Data

Sajian data merupakan suatu rakitan organisasi informasi, deskripsi dalam bentuk narasi yang memungkinkan simpulan penelitian dapat dilakukan. Sajian ini merupakan rangkaian kalimat yang disusun secara logis dan sistematis. Tujuannya agar peneliti bisa memahami objek yang diteliti dan memberikan jawaban sesuai rumusan masalah penelitiannya. Hubungannya dengan tahap penyajian data, peneliti melakukan ringkasan yang 
relevan dengan bidang kajian yang diteliti. Hal ini dilakukan agar memudahkan peneliti dalam mengelompokkan dan menentukan simpulan.

3. Tahap Penarikan Kesimpulan

Tahap simpulan merupakan tahap akhir dalam analisis data ini. Berbagai data yang dibutuhkan untuk penarikan suatu simpulan mulai dianalisis secara lebih mendalam. Hal ini dilakukan agar penelitian kualitatif ini bisa dipertanggungjawabkan kebenarannya. Di samping itu, adanya data-data yang dikumpulkan dapat dijadikan suatu pertimbangan yang akan menentukan arah suatu kajian yang diteliti.

\section{Hasil Penelitian}

\section{A. Paparan Data}

\section{Profil Desa Bampalola}

Desa Bampalola terletak di Kecamatan Alor Barat Laut Kabupaten Alor. Desa ini memilki luas wilayah administratif sebesar 95,25 ha/km, dengan ketinggian $400 \mathrm{~m}$ dari permukaan laut. Jarak dari ibu kota kabupaten ke Desa Bampalola yaitu 15 $\mathrm{km}$. Desa ini terbagi atas 2 dusun yaitu dusun Moafen dan dusun Maebang. Wilayah desa Bampalola memilki batasbatas sebagai berikut:

Tabel 4.1. Batas Wilayah Desa Bampalola

\begin{tabular}{|l|l|l|}
\hline No. & $\begin{array}{l}\text { Batas } \\
\text { Wilayah }\end{array}$ & Nama Daerah \\
\hline
\end{tabular}

\begin{tabular}{|l|l|l|}
\hline 1. & Utara & Desa Oa Mate \\
\hline 2. & Selatan & $\begin{array}{l}\text { Desa Lewalu dan } \\
\text { Desa Lewolang }\end{array}$ \\
\hline 3. & Barat & Desa Hulnani \\
\hline 4. & Timur & $\begin{array}{l}\text { Desa Dulolong } \\
\text { Barat }\end{array}$ \\
\hline
\end{tabular}

Sumber: Batas Wilayah Desa Bampalola

Dari tabel 4.1. tersebut diatas memberikan gambaran bahwa wilayah desa Bampalola yang terletak pada sebuah bukit. Desa Bampalola menjadi salah satu kebudayaan Indonesia dimana masyarakatnya mempunyai kepercayaan dan tradisi dengan alam.

\section{Keadaan Sosial Ekonomi}

Keadaan sosial ekonomi merupakan keadaan kehidupan penduduk suatu tempat dilihat dari segi sosial dan ekonomi. Keadaan sosial ekonomi sangat dipengaruhi oleh letak geografis tempat tersebut. berikut ada beberapa faktor yang menjadi patokan bagi desa Bampalola.

a. Mata Pencaharian

Keadaan geografis desa Bampalola yang terletak di atas gunung dan cukup jauh dari perkotaan membuat masyarakat desa ini mayoritasnya bekerja sebagai petani lahan kering. Hal ini dapat dijelaskan pada Tabel berikut:

Tabel 4. 2. Mata Pencaharian Masyarakat Desa Bampalola Tahun 2014

\begin{tabular}{|l|l|l|l|}
\hline No & $\begin{array}{l}\text { Jenis } \\
\text { Pekerjaan }\end{array}$ & Jumlah & Presentasi \\
\hline 1 & Petani & 1094 & $97,94 \%$ \\
\hline
\end{tabular}




\begin{tabular}{|l|l|l|l|}
\hline 2 & PNS & 5 & $0,44 \%$ \\
\hline 3 & Honorer & 8 & $0,71 \%$ \\
\hline 4 & Wiraswasta & 10 & $0,80 \%$ \\
\hline \multicolumn{2}{|l|}{ Total } & 1117 & $100 \%$ \\
\hline
\end{tabular}

Sumber: Kantor Desa Bampalola Tahun 2014

Tabel 4.2. menunjukan bahwa penduduk dengan mata pencaharian paling banyak adalah petani yaitu sebesar 97,94\%, diikuti dengan wiraswasta sebesar 0,89\%, honorer $0,71 \%$, dan yang terakhir adalah PNS sebesar $0,44 \%$.

b. Pertanian dan Perkebunan

$\begin{array}{cl}\text { Pertanian } & \text { merupakan mata } \\ \text { pencaharian } & \text { sebagian besar }\end{array}$
masyarakat desa Bampalola. Hal ini didukung oleh keadaan geografis dan tingkat pendidikan masyarakat desa yang sangat minim sehingga masyarakat banyak yang memilih menjadi petani. Hasil pertanian desa ini antara lain jagung, kacang hijau, ubi jalar, dan singkong, sedangkan hasil perkebunan berupa kemiri, kelapa, kenari, dan kopi.

c. Peternakan

Beternak bukan merupakan mata pencaharian utama masyarakat desa Bampalola. Namun hampir semua kepala keluarga memilki ternak peliharaan seperti ayam, bebek, dan kambing.

\section{Keadaan Sosial Budaya}

a. Penduduk

Berdasarkan data yang ada, penduduk desa Bampalola berjumlah 1.117 jiwa. Diketahui bahwa jumlah penduduk dusun Moafen dan Maebang hanya berselisih 1 (satu) jiwa saja. Tetapi jumlah penduduk terbanyak yaitu dusun Maebang yaitu 559 jiwa.

b. Agama

Agama merupakan suatu lembaga atau institusi yang mengatur kehidupan rohani manusia. Manusia memilki kemampuan terbatas, kesadaran pengakuan akan keterbatasaannya menjadikan keyakinan bahwa ada sesuatu yang lebih di luar dirinya. Agama yang dianut oleh seluruh penduduk di desa Bampalola yaitu agama Islam.

\begin{tabular}{|c|c|c|c|c|}
\hline \multirow[t]{2}{*}{$\begin{array}{l}\mathrm{N} \\
\mathrm{O}\end{array}$} & \multirow[t]{2}{*}{$\begin{array}{l}\text { Nama } \\
\text { Dusun }\end{array}$} & \multicolumn{2}{|c|}{$\begin{array}{l}\text { Jenis } \\
\text { Kelamin }\end{array}$} & \multirow[t]{2}{*}{ Jumlah } \\
\hline & & $\mathrm{L}$ & $P$ & \\
\hline 1 & Moafen & 279 & 279 & 558 \\
\hline 2 & Maebang & 279 & 280 & 559 \\
\hline \multicolumn{2}{|c|}{ Total } & 558 & 559 & 1117 \\
\hline
\end{tabular}

c. Pendidikan

Diketahui bahwa tingkat pendidikan di Desa Bampalola yang dimiliki oleh penduduk mayoritasnya adalah tamatan Sekolah Dasar di mana terdapat 523 orang $(47,89 \%)$ dari 1.117 jiwa 


penduduk. Pendidikan telah
mendapat perhatian dari
masyarakat dan pemerintah
setempat ditandai dengan gencarnya
usaha akan program wajib belajar
sehingga anak-anak dan remaja
umumnya dapat melanjutkan
pendidikan hingga perguruan tinggi
walaupaun masih ada penduduk
yang tidak sekolah. Hal ini
dikarenakan kondisi ekonomi yang
tidak memungkinkan untuk
menempuh pendidikan.

4. Keadaan Pemerintahan

1) Pemerintahan Adat

Dalam struktur kepengurusan adat masyarakat Bampalola, dipimpin oleh para tua adat dari 5 suku besar yang ada antara lain suku Afen Lelang, Lamui Lelang, Marang Lelang, Kafin Lelang, dan Mor Lelang. Pemerintahan adat masih dijalankan oleh masyarakat desa Bampalola.

Biasanya pemerintahan adat ini dilaksanakan apabila ada upacara adat, dan apabila ada anggota masyarakat yang melanggar hukum adat maka pemerintahan adat yang bertugas memberikan hukuman. Keadaan pemerintahan adat di desa Bampalola sampai sekarang masih berjalan dengan baik dan ditaati oleh semua warga di desa ini.

2) Pemerintahan Desa
Desa Bampalola dipimpin oleh seorang kepala desa dan dibantu oleh aparat desa lainnya. Desa Bampalola yang terdiri dari 2 (dua) dusun ini memiliki kepala dusunnya masing-masing.

Dalam menjalankan setiap roda pemerintahan, setiap unsur-unsur pemerintahan melaksanakan tugasnya dengan baik. Selain itu, terdapat suatu badan yang bertugas mengontrol jalannya roda pemerintahan yaitu Badan Permusyawaratan Desa (BPD) desa Bampalola.

\section{B. Temuan Penelitian}

1. Sejarah Rumah Adat Lakatuil di Desa Bapalola

Menurut N-01 dan N-02, serorang tokoh ketua adat dan Kepala Desa Bampalola desa Bampalola mengungkapkan bahwa, bampalol paliho percaya kalo o'bapak baraho tura fa'amifem latela yang mema pi ebisa edun'a. Jarihoroba sekara pi aholu ane Raja Tanah (foaifen). Raja Tanah heu feta kira-kira pada taun arnufali tofa dan name altaho barpi ebisa ahul kalo raja tanah heu ho tarofemi feho. Ada gua yang nuheuro name percaya bahwa raja tanah heumi lateila yang sekarang ba aneuba Tula Gadong atau rumah Tuhan. Raja Tanah elufa he ja buifed ara nikah. Jipi ja tempat ane kampong lama yang sekarang ba piaholu Ba Mate ipale 
doita efalmi heu. Jona alo oba lote banu ugahi supaya binata-binata ebisa jipi ade horo ba Raja Tanah banu ugahi yang sekarang bane Lakatuil heu yang artinya fifi dan lafeni. Fifi heu berarti ba yang kua dari Lakatuil ba sedangkan ane lafeni heu ba yang name ugahi pas ma jo Sumatra paliheunin.

Berdasarkan kalimat diatas dapat dimaknai bahwa masyarakat desa Bampalola percaya nenek moyang mereka berasal dari tanah atau timbul secara ghaib dari dalam tanah. Ia disebut dengan nama Raja Tanah (foaifen). Raja Tanah sendiri hidup sekitar pada abad ke-13 dan tidak ada satu orangpun yang tau dari mana Raja Tanah itu berasal. Gua tempat munculny raja tanah di debut dengan nama tula gadong yang artinya rumah Tuhan.

Raja Tanah kemudian menikah dengan Buifedi. Mereka kemudian tinggal di kampung lama di bawa kaki gunung Raja. Untuk memenuhi kebutuhan hidup dan melindungi diri dari hewan buas, maka Raja Tanah dan istrinya membangun sebuah rumah yang diberi nama Laktuil yang artinya merah dan tinggi. Merah menandakan keberanian dan keperkasaan dari rumah adat lakatuil, sedangkan tinggi karena rumah adat dibuat seperti rumah panggung dan memiliki atap berbentuk limas yang tinggi (Wawancara, 24 Juli 2014).

Pada awal abad ke-14 kampung lama (Lakatuil) menjadi salah satu kerajaan besar di pulau alor yakni kerajaan Lakatuil. Kerajaan Laktuil mencapai puncak kejayaannya pada masa pemerintahan Raja Baololong, dan memiliki wilayah yang luas dihampir sebagian Pulau Alor. Salah satu cara Raja Baololong mempertahankan wilayah kekuasaanya yakni dengan mengirimkan utusan untuk menetap atau tinggal diwilayah yang dikuasai kerajaan Laktuil pada masa itu. Sehingga sampai sekarang banyak turunan dari Bampalola yang ada di sebagian pulau alor. Pada akhir abad ke-14 raja Baololong meninggal dunia dan akhirnya kerajaan Lakatuil mengalami kemerosotan dan punah (Wawancara N-03, 25 Juli 2014).

Seiring berjalannya waktu masyarakat yang hidup dikampung lama makin bertambah sedangkan kampung lama yang sempit dan letaknya yang dikelilingi oleh jurang tidak memungkinkan untuk masyarakat tinggal disana. Maka mereka memutuskan untuk pindah ke kampung yang baru yang lebih luas, dan kampung itu di beri nama Bampalola yang di ambil dari bahasa adang bang yang berarti rumah atau kampung dan palol yang berarti pamali atau tabu. 
Jadi desa Bampalola merupakan sebuah kampung yang menyimpan banyak hal-hal yang berbau pamali atau tabu. Jarak dari kampung lama ke desa Bampalola yaitu $1 \mathrm{~km}$. Pada abad ke-16 agama islam mulai masuk ke desa Bampalola dibawa oleh sultran Najamudin (Oilelang yang berasal dari desa Hulnani. Sebelumnya masyarakat bampalola menganut paham animisme dan dinamisme. (Wawancara N-03, 25 Juli 2014). Menurut N-04, bahwa setelah agama Islam masuk masyarakat mulai melupakan kebiasaanya yang menyembah pohon dan batu-batu besar. Pada awal abad 20 sebelum Indonesia merdeka desa Bampalola berada di bawah ketemukungan Dulolong (anbang). Dan dikuasai bangsa Barat.

Setelah Indonesia merdeka dan pada tahun 1965, masyarakat bampalola hidup seperti masyarakat biasa pada umunya yaitu bertani, berkebun dan mengelola hasil hutan. (Wawancara, 27 Juli 2014). Namun pada tahun 1965 desa Bampalola mengalami musibah yaitu terjadi musim kelaparan yang berkepanjangan dan hasil kebun dan hutan tidak ada yang berhasil sehingga tidak ada bahan makanan yang bisa diolah menjadi makanan, pohon kelapa, jeruk dan ubiubian semuanya diserang hama dan pada saat itu juga desa Bampalola yang letaknya di gunung sehingga tidak memungkinkan untuk mendapat bantuan dari pemerintah karena tidak adanya jalur transportasi.

Masyarakat semuanya menjadi kebingungan dengan musibah ini terutama para tua-tua adat yang ada di desa Bampalola. (Wawancara N-02, 24 Juli 2014). Pada saat musibah kelaparan masih melanda desa Bampalola seorang tua adat dari suku afien lelang yang bernama Ali Adang (alm) mendapat petunjuk lewat sebuah mimpi dimana dalam mimpi tersebut dia didatangi leluhur bampalola dan mendapat petunjuk tentang rumah adat Laktuil, besoknya ia pergi ke kampung lama dan menemukan salah satu tiang sudut dari rumah adat lakatuil yang masih ada.

\section{Kemudian Ali Adang pulang} kembali ke kampung kemudian menceritakan mimpinya kepada para tua adat dari suku yang lainnya dan sesepu kampung. Dan keesokan harinya mereka semua bersepakat berkumpul dan menuju ke kampung lama (doita) di sana mereka menemukan satu tiang dari rumah adat Lakatuil dan kuburan Raja Tanah beserta istri dan anaknya, mereka juga menemukan gua tempat keluarnya raja Tanah.

Setelah kejadian itu masyarakat semuanya berkumpul dan melakukan musyawarah mereka sepakat mencari 
ke tiga tiang sudut yang mirip dengan tiang yang ditemukan.

Maka mereka mencarinya di hutan, dan ketiga kayu tersebut mereka dapat di hutan desa Alila setelah mendapat kayu yang mirip dengan tiang yang ditemukan kemudian mereka membawa kayu yersebut ke kampung lama (doita) dan mulai membangun kembali rumah adat lakatuil sesuai dengan petunjuk mimpi dari Ali Adang tersebut.

N-04 melanjutkan bahwa, seluruh masyarakatBampalola mengerjakannya secara gotong royong. Setelah rumah adat selesai dibuat maka musim kelaparan yang melenda desa Bampalola juga hilang, tanaman dan hasil hutan masyarakat kembali subur dan dapat diolah menjadi makanan. Kehidupan masyarakat mulai membaik.

Setelah kejadian tersebut maka rumah Lakatuil di jadikan rumah adat di desa Bampalola. Setelah rumah adat lakatuil dibangun maka suku-suku yang lain mulai membangun rumah adat yang lain. Dan kampung lama (doita) tempat berdirinya rumah adat Lakatuil di jadikan kampung Adat. Karena di kampung lama terdapat kuburan raja tanah, istri dan anaknya dan di sana juga terdapat peninggalan leluhur yaitu gua tempat munculnya raja tanah, (Wawancara, 27 Juli 2014).

\section{Fungsi Rumah Adat Lakatuil}

Rumah adat memiliki berbagai fungsi dalam kehidupan masyarakat. Salah satunya adalah Rumah adat Lakatuil yang berfungsi sebagai tempat untuk menyimpan benda-benda purbakala atau cagar budaya. Rumah adat Lakatuil memiliki berbagai fungsi dalam kehidupan masyarakat Bampalola. Fungsi tersebut antara lain Pertama Rumah adat Lakatuil berfungsi sebagai tempat tersimpannya benda-benda purbakala atau cagar budaya seperti moko dan gong. Kedua benda tersebut disimpan di ruangan khusus dalam rumah adat. Moko dan gong yang disimpan dalam rumah adat ini berjumlah sekitar 100 buah.

Hal ini juga membuktikan bahwa wilayah Kabupaten Alor memilki kekayaan budaya khususnya bendabenda purbakala yang memiliki nilai seni yang tinggi dan merupakan warisan budaya yang harus terus dilestarikan. Kedua Rumah adat Lakatuil berfungsi sebagai tempat berkumpulnya masyarakat Bamapalola untuk musyawarah mufakat.

Masyarakat Bampalola sendiri terbagi dalam 5 (lima) suku besar antara lain: Afen Lelang, Lamui Lelang, Marang Lelang, Kafin Lelang dan Mor Lelang. Ketiga Rumah adat Lakatuil berfungsi sebagai tempat pelaksanaan berbagai upacara adat seperti upacara makan padi 
baru (ala baloe) dan makan jagung baru (bate baloe). Selain itu juga sebagai tempat untuk melakukan berbagai ucapan syukur atas suatu kesuksesan yang dicapai oleh warga masyarakat Bampalola. Misalnya ada warga Bampalola yang lulus mengikuti tes CPNS maka dia akan wajib melakukan upacara syukuran di rumah adat.

Keempat Rumah adat Lakatuil berfungsi sebagai tempat untuk menyelesaikan berbagai masalah adat dalam masyarakat Bampalola. Misalnya apabila ada masalah batas tanah antara suku maka akan diselesaikan di rumah adat, Kelima Rumah adat Lakatuil berfungsi sebagai tempat berkumpulnya para tokoh-tokoh adat dari 10 (sepuluh) kampung Adang yaitu Bampalola, Hulnani, Kokar, Lewalu, Ampera, Alila, Ilawe, Batu putih, Tobang, Anlawening, 3 (tiga) kampung Alor yaitu Dulolong, Alor Kecil dan Alor Besar dan 7 (tujuh) pulau yaitu pulau Buaya, Ternate, Tereweng, Pura, Pantar, Pura kecil, Kepa.

Mereka semua adalah turunan asli dari desa Bampalola yang menyebar di berbagai tempat di Kabupaten Alor. Mereka akan berkumpul setahun sekali untuk tetap menjaga tali persaudaraan di antara mereka. Keenam Rumah adat Lakatuil juga berfungsi sebagai obyek wisata bagi para wisatawan baik wisatawan domestik maupun mancanegara (Wawancara N-05, 02 Agustus 2014).

\section{Makna Ukiran yang ada di Rumah}

\section{Adat Lakatuil}

Masalah ukir tidak dapat di pisahkan dengan dunia seni, khususnya seni rupa yang di dalamnya penuh dengan keindahan dan kehalusan rasa. Karya seni ukir merupakan karya kasat mata yang kangsung dapat dinikmati oleh semua orang, baik dari wujud dasarnya maupun teknik yang digunakan. Dilihat dari desainnya menunjukkan gambar hiasan yang berulang-ulang maupun sambung menyambung satu dengan yang lain. Rumah adat Lakatuil memilki bentuk yang unik. Pada rumah adat ini terdapat berbagai ukiran dengan bentuk yang berbeda dan memiliki arti tersendiri. Adapun ukiran-ukiran tersebut antara lain yaitu ukiran naga, ukiran burung gagak dan ukiran pada tiang rumah adat.

a) Makna ukiran Naga (Mon Mate)

Pada rumah adat Lakatuil terdapat ukiran naga yang terletak di bumbungan atau puncak rumah adat dan di samping bagian kiri dan kanan rumah adat. Ukiran naga ini memiliki makna tersendiri yaitu binatang naga sendiri dianggap sebagai penunjuk jalan kepada nenek moyang masyarakat Bampalola khususnya raja tanah (Fo'aifen) yang dahulu tinggal dan menetap di dalam gua untuk keluar ke alam bebas dan 
melanjutkan hidup mereka di sana. Masyarakat Bampalola percaya bahwa dahulu leluhur mereka hanya tinggal di dalam gua, tetapi melalui petunjuk dari naga tersebut maka sampai sekarang mereka sudah bisa hidup di alam bebas.

b) Makna ukiran Burung Gagak

Menurut cerita, dalam kehidupan masyarakat Bampalola jika dulu ada yang meninggal maka mayatnya tidak dikuburkan tetapi dibuang ke jurang. Suatu saat, anak pertama dari Fo'aifen meninggal dunia. Ia kemudian mendapat mimpi melihat dua ekor burung gagak bertengkar merebut makanan. Salah seekor burung gagak tersebut kemudian mati, dan gagak yang satunya mengais tanah dan mengubur gagak yang mati. Hal ini kemudian memberikan inspirasi dan petunjuk kepada Fo'afen untuk tidak membuang mayat anaknya ke jurang tetapi menguburnya dalam tanah. Dari cerita tersebut, maka sampai saat ini masyarakat percaya bahwa burung gagak sangat berjasa dalam kehidupan leluhur mereka yang kemudian diwujudkan dalam simbol ukiran gagak pada rumah adat Lakatuil.

c) Makna ukiran motif tiang Rumah Adat

$$
\text { Menurut N-03 menjelaskan }
$$

bahwa Rumah adat Lakatuil merupakan rumah adat yang berbentuk rumah panggung. Pada bagian bawah rumah adat, terdapat empat tiang penyanggah sebagai penopang rumah adat. Tiangtiang ini memiliki ukiran-ukiran dengan berbagai bentuk. Adapun makna dari ukiran tersebut yaitu melambangkan anggota tubuh manusia sendiri. Ini juga melambangkan peran leluhur dalam menjaga rumah adat dan mereka sebagai pelindung dan penopang masyarakat Bampalola, (Wawancara, 27 Juli 2014).

Dari penjelasan di atas, menggambarkan bahwa semua ukiran yang terdapat pada rumah adat Lakatuil memiliki makna yang berbeda-beda. Ukiran-ukiran tersebut diukir pada kayu bapasa dengan menggunakan alat-alat tradisonal. Orang-orang yang membuat ukiran adalah mereka yang memiliki keahlian dalam bidang ukir.

Semua ukiran yang ada pada rumah adat Lakatuil diwarnai dengan cat berwarna merah, putih dan hitam. Masing-masing warna memiliki makna yang berbeda-beda. Warna merah melambangkan kesatriaan dari rumah adat Lakatuil dan juga melambangkan kehidupan masyarakat Bampalola di bidang pemerintahan. Warna putih melambangkan kehidupan masyarakat Bampalola di bidang agama.

Warna hitam melambangkan kehidupan Masyarakat Bampalola di bidang adat. Adapun makna umum dari warna-warna yang terdapat dalam ukiran-ukiran tersebut adalah kehidupan masyarakat Bampalola bernaung pada 
tiga batu tungku yaitu pemerintahan, agama dan adat. Aturan-aturan adat yang ada harus dipatuhi dalam setiap kehidupan masyarakat Bampalola (Wawancara N-01 30 Juli 2014).

\section{Nilai Historis dari Rumah Adat Lakatuil}

Setiap benda atau bangunan bersejarah pasti memiliki nilai-nilai budaya yang sangat tinggi dan bisa kita pelajari sebagai bentuk penghargaan terhadap para leluhur bangsa kita yang telah bersusah payah dalam membangun sebuah kebudayaan. Oleh karena itu, Nilai-nilai tersebut sangatlah bermanfaat bagi masyarakat khususnya para generasi muda, agar tumbuh dan mempunyai rasa nasionalisme pada diri mereka. Begitu pula Rumah Adat Lakatuil ini juga memiliki beberapa nilai-nilai yang sangat tinggi dan bisa kita pelajari serta memiliki nilai-nilai histori dimana Rumah Adat ini mempunyai pengaruh cukup besar bagi masyarakat Desa Bampalola pada khususnya dan Kabupaten Alor NTT pada umumnya.

Seperti yang diungkapkan oleh N-02 bahwa nilai-nilai histori yang bisa diwariskan kepada masyarakat::

a. Nilai sejarah yakni masyarakat mampu memahami dan mengetahui tentang bukti adanya Rumah adat lakatuil di desa Bampalola.

b. Nilai arsiktektur bangunan, yakni kita bisa melihat bahwa bangunan
Rumah adat lakatuil tersebut sama persis dengan rumah-rumah adat yang ada di Sumatra.

c. Nilai pendidikan, yakni kita mampu mengambil nilai-nilai pendidikan untuk selalu semangat dalam mempelajari sejarah bangsa kita sendiri seperti yang telah dicontohkan oleh generasi-generasi sebelum kita.

d. Nilai budaya, yakni Rumah Adat Lakatuil tersebut menjadi salah satu icon penting bagi masyarakat desa Bampalola pada khususnya dan kabupaten Alor pada umumnya yang akan menambah pendapatan daerah, serta menunjang ekonomi masyarakat sekitar (Wawancara 29 Juli 2014).

\section{Nilai Filosofi dari Rumah Adat} Lakatuil

Dalam sebuah kehidupan bersejarah masyarakat tentu akan merasakan bahwa sebuah kebudayaan itu sangatlah penting dan sebagai suatu kehormatan yang ada dalam masyarakat tersebut. Oleh karena itu, pola kehidupan yang berbudaya luhur, dalam hal ini Rumah Adat Lakatuil yang akan menjadi tonggak kebudayaan hidup masyarakat desa Bampalola tentu dapat menarik masyarakat luar untuk datang berkunjung atau berwisata.

Seperti yang dijelaskan oleh N-03 bahwa nilai-nilai filosofi yang dapat 
diambil adalah masyarakat dapat memahami dan mengerti akan perkembangan zaman dan mampu berpikir secara sisteamtis bahwa kebudayaan Rumah Adat Lakatuil itu bisa menarik perhatian para pengunjung.

Akan tetapi upaya pelestarian dan penjagaan terus ditingkatkan sehingga seluruh bagian-bagian tertentu dari rumah itu tetap terlihat menarik dan bagus (Wawancara, 27 Juli 2014).

\section{Potensi Rumah Adat Lakatuil} Sebagai Sumber Belajar Sejarah

Rumah Adat Lakatuil ini bisa dijadikan sebagai sumber belajar sejarah selain sumber dari buku, Rumah Adat Lakatuil berisi tentang peninggalanpeninggalan kebudayaan di Indonesia khususnya di desa Bampalola.

Rumah Adat Lakatuil sebagai sumber belajar sejarah ini dapat direlevansikan disekolah tingkat SMA kelas XI. Peserta didik kita bisa diajak berkunjung ke Rumah Adat Lakatuil tersebut untuk mengamati/observasi terhadap benda-benda peninggalan yang ada didalam maupun diluar Rumah Adat tersebut di Indonesia khususnya di desa Bampalola. Selain benda-benda yang ada di Rumah Adat tersebut mempunyai cerita sejarah yang unik dan bisa diamati untuk meteri belajar mereka (Wawancara N-03, 27 Juli 2014).

N-03 juga menambahkan bahwa, kegiatan belajar mengajar itu tidak hanya dilakukan di dalam kelas, namun bisa juga dilakukan di luar kelas misalnya berkunjung ke tempat-tempat bersejarah, ke museum, atau ke laboratorium. Khusus mata pelajaran IPS/sejarah itu perlu kegiatan belajar mengajar yang dilaksanakan di luar sekolah supaya terjadi kegiatan belajar mengajar yang menarik. Selain itu kalau kita belajar sejarah harus ada buktinya, karena kalau tidak ada buktinya bukan dikatakan sejarah.

Maksud sebagai bukti itu bisa diartikan sebagai jejak-jejak peninggalannya, seperti bangunan, fosil, foto, surat, maupun rekaman video. Bangunan rumah adat Lakatuil ini berupa rumah panggung berdinding bambu, dan diatapi dengan rumput ilalang yang berbentuk kerucut.

Pada bagian atasnya berukiran naga yang sedang membuka mulut menjurus ke arah Timur yang merupakan arah terbitnya matahari. Ciri khas dari rumah adat Lakatuil adalah sebuah tangga yang menghubungkan tanah dengan rumah panggung juga berukiran naga.

Adanya Rumah Adat Lakatuil tersebut peserta didik bisa diajak berkunjung untuk mengamati peninggalan-peninggalan yang ada di Rumah Adat Lakatuil. Harapannya peserta didik bisa langsung melihat dan memahami dengan nyata bahwa Rumah 
Adat Lakatuil tersebut memang asli peninggalan-peninggalan bangsa Indonesia yang berasal dari desa Bampalola. Akhirnya tumbuhlah rasa nasionalisme yang tinggi dan menghormati peninggalan-peninggalan kebudayaan nenek moyang bangsa Indonesia (Wawancara 27 Juli 2014).

\section{Penutup}

\section{Simpulan}

Berdasarkan paparan data dan temuan penelitian dan pembahasan yang dijelaskan dalam bab-bab terdahulu maka dapat disimpulkan rumah Adat Lakatuil adalah rumah panggung yang berdinding bambu diatapi rumput ilalang berbentuk kerucut. Pada bagian puncak berukiran ular naga yang sedang membuka mulut menjurus kearah timur atau terbitnya matahari.

Ciri khas yang lain adalah sebuah tangga yang menghubungkan tanah dan rumah panggung juga terdapat naga yang membuka mulut pada bagian kanan sedangkan bagian kiri terdapat sebuah rantai yang berfungsi sebagai pegangan pada tangan kiri sedangkan disamping kanan Rumah Adat Lakatuil terdapat Mezba yang berfungsi untuk tempat upacara adat dan tarian lego-lego diperagakan dalam sebuah adat dan atraksi budaya.

Dalam Rumah adat tersebut juga banyak peninggalan-peninggalan pusaka seperti Moko dan Gong. Konon menurut sumber yang dipercaya terdapat sebuah gong Asli. Bagi masyarakat Bampalola atau pengunjung yang hendak memasuki rumah adat harus menanggal kasut atau alas kaki karena tempat itu suci dan tidak boleh berbicara dengan kata-kata kotor. Setiap pengunjung yang hendak memasuki rumah adat tersebut harus mengawali langkahnya dengan kaki kanan dan tangan kanan dimasukkan kedalam mulut naga yang sedang terbuka sambil tangan kiri memegang rantai tali untuk berjalan menaiki.

Adapun nilai histori dan filosofi dari Rumah Adat Lakatuil adalah Nilai-nilai sejarah seperti nasionalisme, patriotisme, cinta tanah kelahiran, simbol kekeluargaan, kekerabatan yang kuat antara toleransi umat beragama yang bisa dijadikan pedoman generasi saat ini.

Keberadaan Rumah Adat Lakatuil secara khusus bisa dimanfaatkan oleh para pendidik dan peserta didik sebagai salah satu sumber belajar sejarah. Dengan begitu nilai-nilai luhur yang diperoleh Rumah Adat Lakatuil bisa tersampaikan kepada generasi muda. Hal ini bisa diselaraskan dengan kurikulum dan silabus yang ada tentang peninggalan-peninggalan kebudayaan Indonesia yang ada di desa Bampalola. Namun dalam penerapan kegiatan tersebut seorang pengajar haruslah memiliki strategi dan metode yang sangat tepat agar nilainilai yang luhur tersebut bisa diserap dengan baik oleh peserta didik. 


\section{Daftar Pustaka}

Dinas Kebudayaan dan Pariwisata Kabupaten Alor. 2013. Panduan Upacara Adat Alabaloy BampalolaKabupaten Alor. Bampalola: Alor

Fathoni, A. 2006. Metodologi Penelitian dan Teknik Penyusunan Skripsi. Jakarta: PT. Rineka Putri

Hanif, M. 2012. Pengantar Ilmu Sejarah.. Madiun. Pendidikan Sejarah IKIP PGRI MADIUN.

Hasan, I. 2004. Analisis Data Penelitian dengan Statistik. Jakarta: Bumi Aksara

Herdiansyah H, 2010. Metodologi Penelitian Kualitatif untuk Ilmu-ilmu Sosial. Jakarta: Salemba Humanika

Lutan, R. 2001. Keniscayaan Pluralitas Budaya Daerah (Analisis Dampak Sistem Nilai Budaya Terhadap Eksistensi Bangsa). Bandung: Angkasa

Moleong, L. J. 2011. Metodologi Penelitian Kualitatif. Bandung: PT Remaja Rosdakarya.

Nazir, M. 2009. Metode Penelitian. Bandung: Ghalia Indonesia.

Ndraha, T. 2005. Teori Budaya Organisasi. Jakarta: Rineka Cipta

Prastowo, A. 2014. Memahami Metodemetode Penelitian. Jogjakarta: Ar-Ruzz Media

Pranoto, S.W. 2010. Teori dan Metdologi Sejarah. Ponorogo: Graha Ilmu

Sanjaya, W. 2009. Strategi Pembelajaran Berorientasi Standar Proses Pendidikan. Jakarta: Prenada Media Group

Sejarah Rumah Adat Lakatuil di Desa Bampalola. 2014. Desa Bampalola
Setiadi. E. M. 2007. Ilmu Sosial dan Budaya Dasar. Jakarta: Prenada Media Group

Sitepu, B.P. 2014. Pengembangan Sumber Belajar. Jakarta: PT Raja Gravindo Persada. Jakarta

Slameto. 1991. Proses Belajar Mengajar Dalam Sistem Kredit Semester (SKS). Jakarta: Bumi Aksara

Sugiyono. 2008. Metode Penelitian Manajemen. Bandung: Alfabeta

2009. Metode Penelitian Manajemen. Bandung: Alfabeta

2013. Metode Penelitian Manajemen. Bandung: Alfabeta

Sukmadinata, N.S. 2007. Metodologi Penelitian Pendidikan. Bandung: PT. Remaja Rosdakarya

Suyono dan Hariyanto. 2012. Belajar dan Pembelajaran (Teori dan Konsep Dasar). Bandung: PT. Remaja Rosdakarya

Sutopo, H. B. 2002. Metodologi Penelitian Kualitatif. Surakarta: Sebelas Maret University Press.

Sumber Internet:

Chessmaster Andi. 26 Agustus 2012. Pengertian, Subjek/ Objek Dan Pentingnya Filsafat. (Online), (https://id-

id.facebook.com/notes/chessmaster -andi/-pengertian-subjek-danpentingnyafilsafat/399869676741452, 08 April 2015)

Mitra Baca. 5 Juli 2015. Rumah Adat Indonesia dan Tradisional Khas Daerah .(Online), (http://www.mitrabaca.com/rumah -adat-indonesia-dan-tradisi-onalkhas-daerah.html, 08 April 2015) 
Rifka Putri Kusuma. 29 Maret 2013. Pengertian Filsafat, Pengetahuan, dan Ilmu Pengetahuan. (Online), (https://rifkaputrika.wordpress.com/ 2013/-03/29/iad/ 08 April 2015)

Suprayitno adi purwo, 24 September 2012. Pengertian Ukiran. (Online),(http://pengertianukiran.blo gspot.com/2 08 April 2015)

Wordpress. 2008. Pengertian Sejarah. (Online), (https://serbasejarah.wordpress.com/2008/11/30/pengertiansejarah/), 08 April 2015

Zona Siswa. 15 Agustus 2014. Pengertian Sejarah (Istilah, Bahasa, Para Tokoh. (Online), (http/www.zonasiswa.com/2014/05/ pengertian-sejarah-istilah-bahasapara.html?m=1, 08 April 2015). 